Short communication

\title{
PROCALCITONIN IS NOT A MARKER OF STERILE INFLAMMATION IN DOGS AFTER OVARIOHYSTERECTOMY
}

\author{
GÜRBÜZ Hasan Oğuz, ULUTAŞ Pınar Alkım*
}

Adnan Menderes University Faculty of Veterinary Medicine, Department of Biochemistry, Aydın, Turkey

(Received 09 June, Accepted 04 November 2016)

\begin{abstract}
CRP and WBC are the most widely used markers of inflammation in veterinary clinical diagnosis. Also, PCT is a specific APP marker of bacterial diseases in humans. This study evaluated the levels of PCT, CRP and WBC during postoperative monitoring of bitches undergoing ovariohysterectomy. Thirteen adult clinically healthy female crossbreed dogs aged between 7-24 months were used in the study. Ovariohysterectomy was performed via medial laparotomy using routine procedures. Blood samples were collected from the cephalic vein at 1, 4 and 7 days after surgery (post-op period). Mean serum concentration of PCT, CRP and WBC levels were increased after the surgery. CRP concentrations and WBC counts were increased significantly $(\mathrm{p}<0.001)$ on the first day after the operation and decreased to basal values. However, the PCT rise was not significant. CRP and WBC levels increased rapidly and decreased to normal values in dogs with ovariohysterectomy. CRP and WBC may be of help to determine the possible postoperative complications. Besides, aseptic surgical trauma did not affect PCT levels in dogs. Future studies are needed on canine PCT response focusing on specific bacterial infections.
\end{abstract}

Key words: Procalcitonine, C-reactive protein, WBC, dog, ovariohysterectomy.

\section{INTRODUCTION}

The acute phase reaction (APR), is a nonspecific response that occurs after infection, inflammation, neoplasia or other mechanisms. During the APR, acute phase protein concentrations increase before clinical signs appear [1,2]. Procalcitonin (PCT) consists of 116 amino acids and is produced and secreted by thyroid C cells. During infection and septicemia there is an increase in PCT circulating levels [3]. Production of PCT is regulated by proinflammatory cytokines produced by extrathyroidal organs such as lung, liver, pancreas, colon and other [4,5]. In humans, PCT is a specific acute phase protein (APP) marker in infectious bacterial diseases differentiating between infectious and noninfectious inflammatory diseases [6]. C-reactive protein (CRP) is an APP and has been used for the prognosis and diagnosis of several critical illnesses. CRP is an

\footnotetext{
*Corresponding author: e-mail: paulutas@adu.edu.tr
} 
APP marker of nonspesific inflammation and is used for treatment monitoring in dogs and humans $[2,7,8]$.

Ovariohysterectomy is a commonly used surgical method of contraception and is also the treatment of choice for pyometra and prevention of mammary gland tumors in dogs [2,9] The prevention of postoperative complications depends on the health status of the operated animals. Serum concentrations of CRP and WBC are mostly used as inflammatory markers in clinical diagnostics [10,11]. Clinical symptoms of bacterial infection are nonspecific and the confirmation of the diagnosis is often difficult. When PCT is compared to other markers of infection/inflammation, it seems to be more sensitive and more specific for monitoring bacterial infections in humans [12,13]. For these reasons, the aim of the present study was to evaluate the levels of PCT, CRP and WBC in monitoring postoperative complications in dogs following ovariohysterectomy.

\section{MATERIAL AND METHODS}

Thirteen adult healthy female crossbreed dogs, aged between 7-24 months were used in the study. All dogs were clinically examined; blood samples were collected for routine hematologic and biochemical tests to asses signs of any pathologic condition before the operation. All procedures were approved by the local animal care and use committee and written consents were obtained from the dogs'owners prior to inclusion. Venous blood samples were collected prior to the surgery and post-op on the $1^{\text {st }}, 4^{\text {th }}$ and $7^{\text {th }}$ day for WBC, PCT and CRP analyses.

Ovariohysterectomy was performed via medial laparotomy by routine methods. Dogs were anaesthesized with an intramuscular injection of $2 \mathrm{mg} / \mathrm{kg}$ xylazin and $15 \mathrm{mg} /$ $\mathrm{kg}$ ketamine hydrochloride after 24 hours of starvation. No complications related to anesthesia or hemorrhages were observed during the operation. There were no complications after the surgery and all dogs recovered uneventfully. Serum CRP concentrations were determined by using of a solid phase sandwich immunoassay (Canine CRP kit; Tridelta Development, Ireland). WBC levels were determined by an automatic blood counter (Mindray BC-2800 VET, China). Procalcitonin concentrations were measured by using dog-specific procalcitonin kits (Canine Procalcitonine ELISA Kit, Cusabio, China).

One-way ANOVA of repeated measures and Duncan's test were used to determine the CRP, PCT and WBC concentrations in dogs before and after the operation. The significance level in each case was acceptaed at $\mathrm{p}<0.05$. Pearson's correlation analysis was used to determine the relationship between the mean levels of serum CRP, PCT and WBC . P value of $\mathrm{p}<0.05$ was considered statistically significant.

\section{RESULTS AND DISCUSSION}

The results of this study are shown in Table 1 . The mean serum concentration of PCT was $12.33 \pm 3.80 \mathrm{pg} / \mathrm{mL}$ before the operation. The mean serum PCT level was slightly 
increased on post-op first day but this increase was not significant and reached basal levels on the $4^{\text {th }}$ day after the operation. Before the surgery, mean serum CRP level was $4.47 \pm 1.07 \mu \mathrm{g} / \mathrm{mL}$. This level significantly increased to $43.90 \pm 5.49 \mu \mathrm{g} / \mathrm{mL}$ on the first day after the operation $(\mathrm{p}<0.001)$. CRP level was decreased down to $9.02 \pm 1.37 \mu \mathrm{g} / \mathrm{mL}$ and $8.84 \pm 1.68 \mu \mathrm{g} / \mathrm{mL}$ on day 4 and 7 after the surgery. On days 4 and 7 , the levels of CRP concentration decreased to its pre-op concentrations. Mean blood WBC count was $22.03 \pm 3.1110^{9} / \mathrm{L}$ before the surgery. WBC count was increased significantly $(\mathrm{p}<0.001)$ on the first day after the operation and decreased to $16.50 \pm 1.58$ on day 4 and to $14.89 \pm 1.23$ on day 7 . Serum CRP level was positively correlated with WBC. Serum PCT level was not correlated with CRP and WBC levels (Table 2).

Table 1. Mean serum concentration of CRP, PCT and WBC count in dogs before and after ovariohistrectomy (CRP: C-reactive protein, PCT: Procalcitonin, WBC: White blood cell)

\begin{tabular}{|c|c|c|c|c|c|}
\hline & \multicolumn{4}{|c|}{ Days } & \\
\hline & Preoperation & & Postoperation & & \\
\hline & $\begin{array}{c}0 \\
n=13\end{array}$ & $\begin{array}{c}1 \\
n=13\end{array}$ & $\begin{array}{c}4 \\
n=13\end{array}$ & $\begin{array}{c}7 \\
n=13\end{array}$ & \\
\hline $\begin{array}{c}\text { PCT } \\
(\mathrm{pg} / \mathrm{mL})\end{array}$ & $12.33 \pm 3.80$ & $21,99 \pm 2,47$ & $16.78 \pm 3.71$ & $12.49 \pm 2.52$ & NS \\
\hline $\begin{array}{c}\text { CRP } \\
(\mu \mathrm{g} / \mathrm{mL})\end{array}$ & $4.47 \pm 1.07^{\mathrm{b}}$ & $43.90 \pm 5.49^{a}$ & $9.02 \pm 1.37^{b}$ & $8.84 \pm 1.68^{b}$ & $* * *$ \\
\hline $\begin{array}{c}\text { WBC } \\
\left(10^{9} / \mathrm{L}\right)\end{array}$ & $17.16 \pm 1,60^{\mathrm{b}}$ & $30.11 \pm 2.36^{a}$ & $16.50 \pm 1.58^{b}$ & $14.89 \pm 1.23^{\mathrm{b}}$ & $* * *$ \\
\hline
\end{tabular}

Data represents mean value $\pm \mathrm{SE} . * * * \mathrm{P}<0.001$; NS: Nonsignificant. Statistical difference between groups with different letters in the same line is significant.

Table 2. Values for $\mathrm{r}$ and $\mathrm{p}$ of the relationship between serum PCT, CRP and WBC levels during the pre and postoperative ovariohysterctomy periods

\begin{tabular}{cccc}
\hline & PCT & CRP & WBC \\
\hline \multirow{2}{*}{ PCT } & 1 & $\mathrm{r}=0,244$ & $\mathrm{r}=0.198$ \\
& 0.115 & 0.214 \\
& $\mathrm{NS}$ & $\mathrm{NS}$ \\
CRP & & $\mathrm{r}=0,589^{* *}$ \\
& 1 & 0.000 \\
WBC & & $\mathrm{P}<0.001$ \\
\end{tabular}

**: $\mathrm{P}<0.01$ Correlation is significant at the 0.01 level (2-tailed).

The results of the present study show that plasma PCT levels are not significantly affected by ovariohysterectomy. Available data suggests that no complications occurred related to the surgery. It may be implicated that aseptic surgical trauma did not influence the PCT concentrations and the use of it is limited for monitoring during the 
recovery period. Several animal and human studies have shown a sustained increase in the concentration of plasma PCT during serious infections and induced endotoxemia [4-6]. Yilmaz et al. (2008) reported that PCT rose as a response to endotoxemia in dogs. Kuzi et al. (2008) reported that PCT was used to be a diagnostic and prognostic marker in diseased dogs. One original study reported PCT mRNA expression, indicating that PCT was suggested to be a APP among dogs [6]. Indeed, canine PCT mRNA expression did not differ significantly between infectious and noninfectious diseases. According to the results of the latter study, dogs presented a wider range of their infectious disease and more heterogeneous inflammatory condition and APR.

In the present study, pre-op mean CRP concentration was $4.47 \pm 1.07$, it increased to $43.90 \pm 5.49$ on the first postoperative day. Serum CRP concentration increases approximately 10 folds in dogs undergoing ovariohysterectomy. The mean serum CRP concentration was decreased on day 4 and day 7 post-surgery. Surgical injury to the peritoneum may be related to serosal inflammation. Peritoneal mesothelial cells organize the inflammatory processes. These cells are the source of proinflammatory mediator cytokines such as IL-1 and IL-6. These cytokines increase in tissue injury and local inflammations caused by an increase in CRP concentration [10]. KjelgardHansen et al. (2013) repored that serum CRP response varied according to the degree of surgical trauma and canine serum CRP levels, and would qualify as an inflammation monitoring marker in the postsurgical recovery period. WBC is a marker that helps to show the determination of inflammation and prognosis. In this study, WBC levels were significantly increased and then declined to normal physiological values on the $4^{\text {th }}$ and $7^{\text {th }}$ day. Similarly, several studies have suggested that cytokines, APPs, and other biomarkers of inflammation such as WBC indicate presence of postoperative complications, and might be used to predict short- and long-term outcomes in surgeries [16]. In this study, a positive correlation was observed between serum CRP and WBC levels (in pre and post operative days), but there was no correlation between mean plasma PCT levels with CRP and WBC. The lack of correlation between PCT and other parameters is most likely associated with no complication related to inflammation were observed during seventh day of following the surgery.

In conclusion, CRP and WBC levels of dogs increased rapidly and decreased to normal values after ovariohysterectomy. The postoperative levels of this markers coincided with the recovery period. CRP and WBC may have helpful tools to determine postoperative complications. However, aseptic surgical trauma did not affect the PCT levels in dogs. Future studies on canine PCT response in specific bacterial infections are needed. Specific differences have been described in other APPs that may exist in canine PCT response. Besides, it is essential to develop available gold standard methods for measuring canine PCT levels.

\section{Acknowledgement}

This study was a summary of MS thesis of first author supported by project numbered VTF 13-041, Adnan Menderes University Research Foundation. 


\section{Authors' contributions}

The present study was the master thesis of GHO. GHO collected the samples, performed the analysis and draft the manuscript. UPA was supervisor of the study, and participated in its design and coordination and helped to draft the manuscript.

\section{Declaration of conflicting interests}

The author(s) declared no potential conflicts of interest with respect to the research, authorship, and/or publication of this article.

\section{REFERENCES}

1. Ceron JJ, Eckersall PD, Martynez-Subiela S. Acute phase proteins in dogs and cats: current knowledge and future perspectives. Vet Clin Pathol. 2005, 34: 85-99.

2. Schmidt EMS, Eckersall PD. Acute phase proteins as markers of infectious diseases in small animals. Acta Vet-Beograd.2015, 65(2), 149-161.

3. Nahum E., Schiller O, Livni G, Bitan S, Ashkenazi S, Dagan O. Procalcitonin level as aid fort he diagnosis of bacterial infections following pediatric cardiac surgery. J Crit Care. 2012, 27: 220: 11-16.

4. Lika AB, Kasleci AB, Refatlari E, Allii NH, Barbullushi AJ, Mone I, Mitre A. Serum procalcitonine levels as an earlu diagnostic indicator of sepsis. Mat Sov Med. 2013, 25(1):2325.

5. Joo K, Park W, Lim MJ ,Kwon SR, Yoon J. Serum procalcitonin for differentiating bacterial infection from disease flares in patients with autoimmune diseases. J. Korean. Med. Sci.211, 26: 1151-1147.

6. Kuzi S, Aroch I, Peleg K, Karnieli O, Klement E, Dank G. Canine procalcitonie Messenger RNA expression. J Vet Diagn Invest. 2008, 20:629-633.

7. Dabrowski R, Wawron W, Kostro K. Changes in CRP, SAA and haptoglobin produced in response to ovariohysterectomy in healthy bitches and those with pyometra. Display Settings: Abstract Format Summary. Theriogenology. 2007 Jan 15, 67(2):321-3277.

8. Ulutas B, Bayraml G, Ulutas PA, Karagenc T. Serum concentration of some acute phase proteins in naturally occurring canine babesiosis: preliminary studies. Vet Clin Pathol. 2005, 34: 144-147

9. Vasiljevic M, Ristanovic D, Jovanovic M, Davitkov D, Bosnjal I, Kristic V, Stanimirivic Z. Comparative Analysis of Parameters of Intraoperative and postoperative pain in bitches undergoing laparoscopic or conventional ovariectomy. Acta Vet-Beograd. 2015, 65 (4), 488495.

10. Mikula T, Ciancira J, Wiercinska-Drapalo A. Is there any influence of immune deficit on procalcitonine results.. Human Immunol. 2011, 72:1194-1197.

11. Schuetz P, Albrich W, Mueller B. Procalcitonine for diagnosis of infection and guide to antibiotic decisions: past, present and future. BMC Medicine 2011, 9-107.

12. Hoffmann G, Czechowski M, Schloesser M, Schobersger W. Procalcitonine amplifies inducible nitric oxide synthase gene expression and nitricoxide production in vascular smooth muscle cells. Crit Care Med. 2002, 30(9): 2091-95. 
13. Yo CH, Hsieh PS, Lee SH, WU JY, Chang SS, Tasiş KC, Lee CC. Comparison of the test characteristics of procalcitonine to CRP and Leucocytosis for the detection for the serious bacterial infections in children presenting with fever without source: review and meta analysis. Pediatrics 2012, 60(5): 591-600.

14. Yilmaz Z, Ilcol YO, Ulus IH. Endotoxin increases plasma leptin and ghrelin levels in dogs. Crit Care Med 2008, 36,3: 828-833.

15. Kjelgaard-Hensen M, Storm H, Mikklesen LF, Eriksen T, Jensen AL(2013) Canine serum C-reactive protein as a quantitative marker of the inflammatorry stimulus of aseptic elective soft tissue surgery. Vet Clin Pathol 2013, 42,3: 342-345.

16. Jacobsen S, Nielsen Jv, Kjelgaard-Hansen M, Toelboell T, Fjeldborg J, Halling-Thomsen M, Martinussen T, Thoefner Mb, Acute Phase Response to Surgery of Varying Intensity in Horses:A Preliminary Study. Veterinary Surgery 2009, 38:762-769.

\title{
PROKALCITONIN NIJE MARKER STERILNE INFLAMATORNE REAKCIJE KOD PASA POSLE OVARIOHISTEREKTOMIJE
}

\author{
GÜRBÜZ Hasan Oğuz, ULUTAŞ Pınar Alkım
}

CRP kao i WBC se najčešće koriste kao markeri inflamatorne reakcije u veterinarskoj kliničkoj dijagnozi. Isto tako, PCT je specifični marker za APP bakterijskih infekcija kod ljudi. Ova studija je imala za cilj evaluaciju PCT, CRP i WBC tokom posle operativnog praćenja kuja kod kojih je obavljena ovariohisterektomija. U okviru studije, bilo je 13 mešanaca odraslih klinički zdravih ženki starosti 7 do 24 meseca, kojima je urađena ovariohisterektomija. Ovariohisterektomija je obavljena rutinski, metodom medijalne laparaskojije. Uzorci krvi su sakupljani iz cefalične vene i to jedan, 4. i 7. dana posle operacije. Srednje koncentracije PCT, CRP i WBC u serumu su bile povećane posle operacije. Vrednosti CRP koncentacije kao i broj WBC, bile su značajno povećane $(\mathrm{p}<0,001)$ prvog dana posle operacije posle čega su opale na fiziološke vrednosti. Međutim, PCT porast nije bio statistički značajan. Vrednosti koncentracije CRP kao i broj WBC su ubrzano rasle kao i opadale na normalne vrednosti kod pasa sa ovariohisterektomijom. Vrednosti CRP i WBC mogu da budu korisne u cilju određivanja mogućih posleoperativnih komplikacija. Pored toga, aseptička trauma kao posledica hirurškog zahvata, nije uticala na nivoe PCT kod pasa. Potrebno je da se obave dalja ispitivanja koja bi ispitala PCT odgovor tokom specifičnih infekcija bakterijske etiologije. 